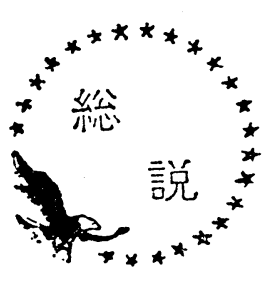

1. ま え がき

消火といら現象は別の言葉でいえば然焼の停止であ るから，この問題を考えるにはまず燃焼の継続に必要 な条件を考え，これに基礎を置いて理論構成をしなく てはならない。しかるによく知られているとおり燃焼 現象そのものがきわめて複雑で, 現在はつきりしない 所が多いため，これの一つの応用である消火もそれ以 上に不明の点が多い。この辺の様子はつい先頃まで消 火の説明といらと，いわゆる燃焼の三要素が必らずと いつてよいほど持出され，またそれ以上の定量的な解 説はほとんど行なわれていないことからもわかる。と ころで消火に関する最近の研究はどうかというと, 戦 後四塩化炭素消火剤に代わつて CB 消火剤が登場し, それに関連してハロゲンの燃焼抑制作用が次第に明ら かになつてきたが，それ以外には特に目立つた発展は なく，したがつて消火の具体的な方法についても原理 的に新しい開発はあまりない現状である。消火がこの ような状態にある理由は他の分野でもそらであるが, 現象が明らかになつていなくても実際に火を消すには 困らないことと，消火のように生産と直接結びつかな い分野は世界的にみて研究者が少ないなどのことが挙 げられるよらに思われるが,それはともかくとして,こ こでは，消火の実際的な面は一切省略して，筆者が燃 燒研究者の立場からみたとき，消火はこのような考え 方で系体化したらどうだろらかという試案を骨子と し，それに付随して最近の現象的な事実を記してみた いと思う。

\section{2. 消火法の分類}

一般に燃焼は熱と流れと化学反応の混り合つた境界 領域の現象である。したがつて，これが継続して起こ るためには，少なくとも上の三つにそれぞれ特有の条 件があるはずである。つまり,(1)熱に関する条件, (2) 化学反応に関する条件および (3) 流れに関する条件 がそれである。もとより，これらの三つは互いに関連 を持つていて独立ではないが，この内第一のものにつ いては，火炎中における化学反応に基ゔく発熱とその
放散の問題がこれに対応していることがわかり，つぎ に第二の化学反応については当然反応の速度が問題に なるが，燃料を固定して考えれば任意にかえられるの は混合気組成だけであるから反応速度を支配する濃度 条件が燃焼の継続を支配し，さらに第三の場合に対し ては炎が安定化されるかどらかがこの条件で定まると みられる。かくて，このように考えてみると消火の場 合にもこれらの条件が問題となり, 消火法も原理的に はつぎの三つに分れるとするのが合理的のようにみえ る。

（1）燃焼の熱的条件による消火

(2) 燃焼の濃度条件による消火

（3）燃焼の安定条件による消火

この分類は前記のとおりあくまでも消火を燃焼現象の 一部として把えたもので, 物理的とか化学的という面 には拘泥しないし，また消火の対象となる物質そのも のにも関倸しない考え方である。以下，各分類につい てもう少し詳しく記そう。

\section{3. 燃焼の熱的条件による消火}

一般に火災に伴う燃焼が継続するためには，火炎内 において化学反応により発生した熱が末燃焼の混合気 の反応を引き起こすために有効に使われなくてはいけ ない。したがつて,何らかの形で熱を奪う操作を火炎に 加えると末燃混合気はその燃焼に必要な熱量を受ける ことができなくなり燃焼は停止する。これが熱的条件 に基づく消火の原理で，吸熱操作は別の言葉でいえば 泠却に当たるから，これは冷却消火法ともいらことが できる。そしてこの場合の消火に必要な条件は放熱速 度が化学反応による発熱速度を上廻る，または発熱に よる未燃ガスの加熱が発火温度以下にとどまるなどの 表現で与えられるが，この点をもら少しわかり易く説 明するとつぎのとおりである。すなわち,いま消火の対 象となつている火炎の熱構造を考えてみると，図１に 示したようになり，これはみずから発熱反応を起こし て温度が上昇する反応域と反応はほとんど起こさず， おもに反応域からの熱伝導により加熱される予熱域と 


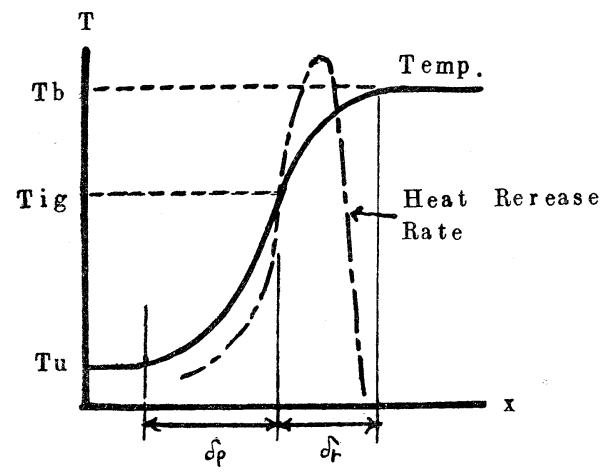

$\mathrm{Tb}$ ：火炎温度, $\mathrm{Tig}$ ：発火温度, $\mathrm{Tu}$ : 未燃 ガス温度， $\delta_{p}$ : 予熱域, $\delta_{r}$ : 反応域

図 1 火炎の熱構造

からなる。そこで，炎が引続いて 維持されるために は，反応域の熱により予熱域の温度がみずから反応を 始得る温度, いいかえれば自然発火温度にまで絶え ず上昇しなくてはならないが，もし，吸熱操作が加 わつて反応域の温度が低下すると予熱域に伝わる熱 が減り,ついには未燃ガスが自然発火温度に達する ことができなくなつて消火が起こることになる。た だし，この場 合の発火温度の值け可燃性混合気を容 器に入れて全面から加熱した時の值よりも高く, むし

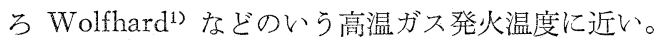

さて，この冷却作用に基づいた具体的な消火法とし ては，原理的に熱容量を利用する方法と相変化に際 しての吸熱を利用する方法が考えられる。まず，前 者は熱容量の大きな物質の添加による泠却が称らい で, 通常不活性な気体と不燃性の固体が対象になる が，気体の場合には量が多く必要なことと経済的に使 用が成立つ適当なガスが見付けにくいといら久点があ り，固体の場合には量は少なくてすむが気一固体間の 熱伝達がわるい点で不利である。いずれにしても，こ の方法消火消必要な量の上加定常火炎を消すに は適当でなく，固体粉末年3)や固体細隙 ${ }^{4)}$ にる伝ぱ火 炎の阻止がそのおもな適用範国である。実際にも，前 者は炭抗において爆発の伝ぱ阻止を目的として岩粉や 無機塩撒布の形式で，また後者は金網, 燒結金属, 多孔 板，波板状金属などを用いたフレームアレスター5)-U して化学工場で, さらには防爆電気機器の安全間隙と して利用されていることは知られているとおりであ そ。なお，細孔による吸熱を実際に適用するに当たつ ては，各種可然性混合気について火炎が伝ぱしなくな る最大の大きさ，つまり消炎直径や消炎距離が测定さ
表 1 可燃性混合気の消炎距離

(理論混合気, 1 気圧, 常温)

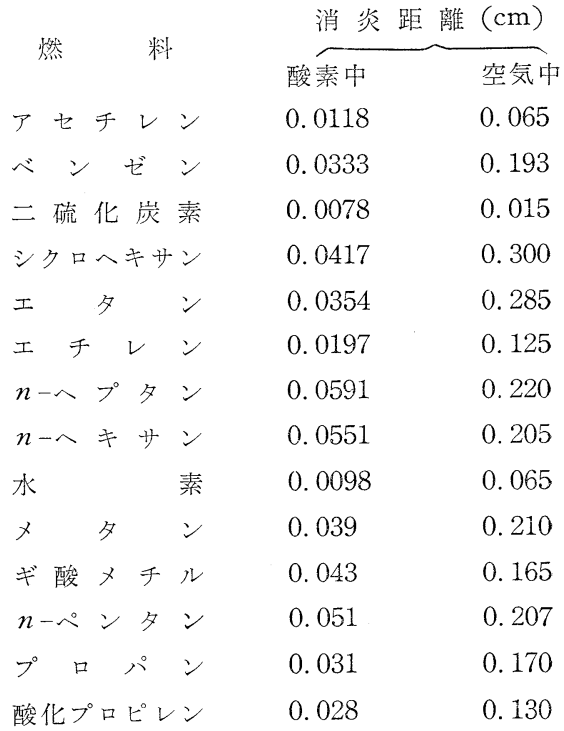

れているから，設計上はこれを規準に取ることがで きる。参考までに表 1 亿は数種の燃料が酸素および空 気と混つた場合の消炎距離を与えた ${ }^{6)}$ 。容易に想像さ れるようにこの值は燃焼速度の大きい燃料で小さく， したがつて水素やアセチレンなどでは消火しにくい。 つぎに相変化による吸熱を用いる方法としては液体 の蒸発熱を利用するものが最も手軽で, 蒸発熱が大き 、，安価で何処ででも手㳊入るなどの点から水が多く 用いられる。しかも，この場合気化のみを目的とする ならば単位体積当たりの表面積が大きい水滴にした方 が有利であるから，実際上注水噴霧や霧の形》で使用 される。水滴の粒径に関しては，半径の減少速度は水 滴半径に逆比例するから，単化冷却だけを目的にすれ ぼ小さい方がよいが，㐫り小さくなると火炎に有効 に適用できない上，後に示すように消火対象物が木材 などのような分解燃燒性物質の場合に注，気相の火炎 を冷却するよりも然料の発生源で岁る固体を冷却する 方が效率がよいので，むしろ粗い水滴が用いられる。

なお，四塩化炭素や $\mathrm{CB}$ のよな液体消火剤の蒸発 熱は $50 \mathrm{cal} / \mathrm{g}$ 位で, 水に較べると $10 \%$ 程度しかない のでこれによる冷却作用はほとんど期待されず，また 炭酸ガスの放出時に生ずる固体炭酸も昇華熱は $138 \mathrm{cal}$ /gと少し大きいが量が少ない（常温で約25\%）ので効 果はほとんどない。

\section{4. 燃焼の濃度条件による消火}

よく知られているように可燃性混合気が燃焼をする 
ためには，混合気組成が特定の濃度範囲にあることが 必要で, この範囲の外ではたとえ他の条件が満足され ても然焼は継続しない。このような限界の生ずる理由 としては然料, 酸素のいずれかが過利になると熱発生 に必要な有効衛突の数が減ることにあると考えられる が，普通この濃度限界は燃燒限界と呼ばれ，とくに燃 料濃度の低い方の限界を下限界, 高い方を上限界とい う。したがつて, 燃料か空気のいずれかを適当な方法 で減少し, 混合気組成を燃焼範囲から脱してやれば然 焼は最早継続しない。また，混合系に不活性な物質を 別に加えてゆくとその三成分系の燃焼範囲は添加量の 増加とともに次第に狭くなり，ついには上限界と下限 界は一致する。そこで，この場合にも添加物質の量が その值にまで達すると消火がおこるわけで，これらが 燃焼の濃度条件による消火の原理である。もら少の具 体的にいらと，たとえばガソリン一空気混合気に二， 三の不燃性ガスを加えた場合, その燃焼範囲は図 2 の ように変化するが8)，この図で曲線の内側のみが燃焼 可能な領域となり，その外では燃焼は起こらない。し たがつて，不然性ガスが曲線のピーク值より多く加え られれば，どんな場合でも消火されるはずで，ガソリ ンの場合, 窒素ガスでは 40\% (容量), 炭酸ガスで 28 \%となる。これに反してフレオン22のような八ロゲン 化炭化水素では $12 \%$ 位と著るしく低い。このような差 の生ずる理由は後に記すが，これから消火に必要な添 加物質の量はこのピーク值の大小で判断されること がわかる。

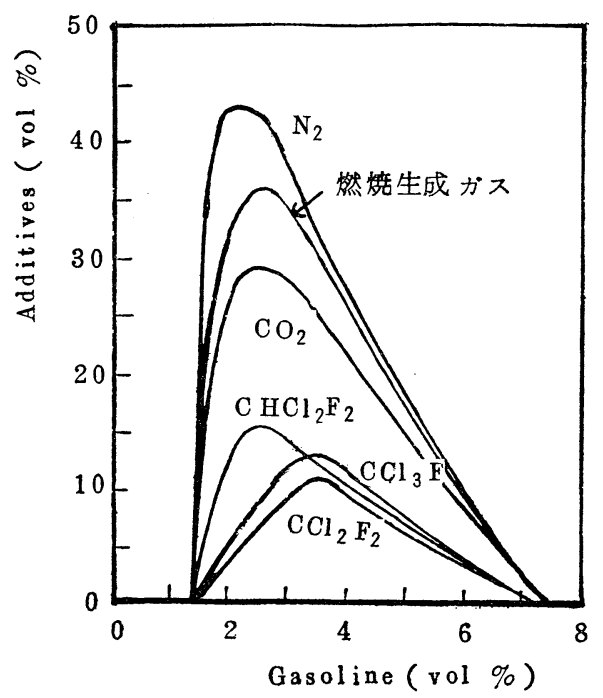

図 2 不燃性ガスを加えた場合のガソリン一空 気混合気の燃焼限界
なお，この濃度条件に基づく消火の中で空気量を減 らして燃料の量を相対的に増し, 混合気濃度が燃焼の 上限界を越えることにより消火する現象は空気が欠乏 するといら意味で窒息作用による消火と呼ぶことも㐫 る。しかし，この言葉は，あくまでも燃燒の上限界を 利用する場合にのみ用いられるべきもので，その他に は適用できない。また，燃燒限界の值は現在のとこ ろ, 燃料と空気の二成分系の場合も添加物の入つた三 成分系の場合も理論的には求められないので, 実験值 を利用するか，または Le Chatelier の経験式などで 推定する以外に方法がないことを付加える。

ところで，ここに述べた方法による具体的な消火法 はきわめて多いが，前記の考え方にしたがつて大別す ると，二成分系の濃度条件を用いる方法と三成分系の 濃度条件による方法に分れる。前者においてまず考え られるの注気体燃料の場合の密閉と然料の除去であ り, 液体, 固体燃料の場合の温度や濃度の低下であ る。まず第一の密閉はすでに記した窒息消火と呼ばれ るもので，空間内の燃料濃度が上限界を越すために起 こる現象であり，第二の燃料の除去は逆に燃料濃度が 下限界以下になつて消火されるわけである。空気泡 ${ }^{97}$, 高膨張泡 ${ }^{10)}$, 界面活性剤水溶液による被覆 ${ }^{11)}$ ，さらに 蓋による消火などはいずれも密閉に属す方法といえ る。一方，燃料が液体や固体の場合には，不均一系の 燃焼となり，可燃性ガスの供給に蒸発や分解などの過 程が関与するため, 直接気相における燃焼反応を阻止 しないでも，蒸発や分解の速度を低下させることによ り可燃性ガスの量を減らし，混合気濃度を下限界以下 にして消火することができる。そして，このためには 蒸気圧が clausius-clapeyron の式によつて液体の温度 に関係し，熱分解速度が Arrhenius の式によれて加熱 温度に結びついていることを利用して液体，固体の温 度または濃度低下を衫らら。石油貯蔵タンクの消火に 燃焼時の液面下の温度分布が表面から下にほぼ指数的 に減少していることを用い，攪拌によつて表面温度を 下げる方法 ${ }^{12)}$ や前にも少し触れたように木材の燃焼を 固体部分に注水することによつて消火する方法，さら には水溶性の液体の燃焼を落下水槽を用いて消火する なでは，この代表的な例である。もとより，攪拌によ る消火は液体の引火温度が気温より低、場合にはいく ら平均化して温度を下げても下限界以上の蒸気圧を液 体が持つので消火はできないが，いずれにしてもこの ような消火法は燃燒限界值さえわかつていれば，合理 的に設計することができる。さらに燃焼が不均一系の 場合には，液体や固体の加熱はみずからの炎以外には 
なく，またその場 合の熱伝達は熱輻射が主であるか ら，不然性の粉末を燃焼空間に浮遊させるなどの方法 で火炎から境界面への熱の伝達を減らすことにより温

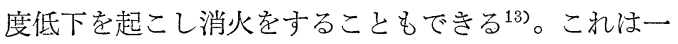
種の遮蔽効果による消火であるが, 原理的にはここに 入る。

つぎに後者の具体的な方法としては, 炭酸ガス, 窒 素ガス, 水蒸気などによる消火がしばしば用いられて いるが，前にも触れたとおり，その効果は燃燒限界曲 線のピーク值の小さい方が大きから窒素ガスよりは 水蒸気，それよりも炭酸ガスが優れていることにな る。この点は図 2 のガソリンの例から想像されるとお りである。もともと，これらの不活性ガスの燃焼に対 する妨害作用は単なる物理的な希釈作用にすぎないか ら，これらの順序はおもに熱的な性質の差によると考 えてよいが，このよらにして然燒限界のピーク值が決 まると，それに対応した然料と空気比が定まり，これ から消火がおこるために必要な酸素ガス量がわかる。 そこでいまこの值を窒素ガスと炭酸ガスで希釈する場 合に各種の燃料について求めてみると表 2 のよりな る14)。これをみると面白いことにこのようにして求め た燃焼の限界酸素量は水素と一酸化炭素の例外を除け ぼ，すべて然料の種類にかかわらずほぼ一定值を示 し，窒素ガスの場合約 11\%，炭酸ガスでは約 $14 \%$ と なる。なぜこのように一定になるかはいまだ詳細に 検討されていないが, 昔から燃燒は空気中の酸素濃

\section{表 2 各種燃料の限界酸素量}

(1 気圧, 常温)

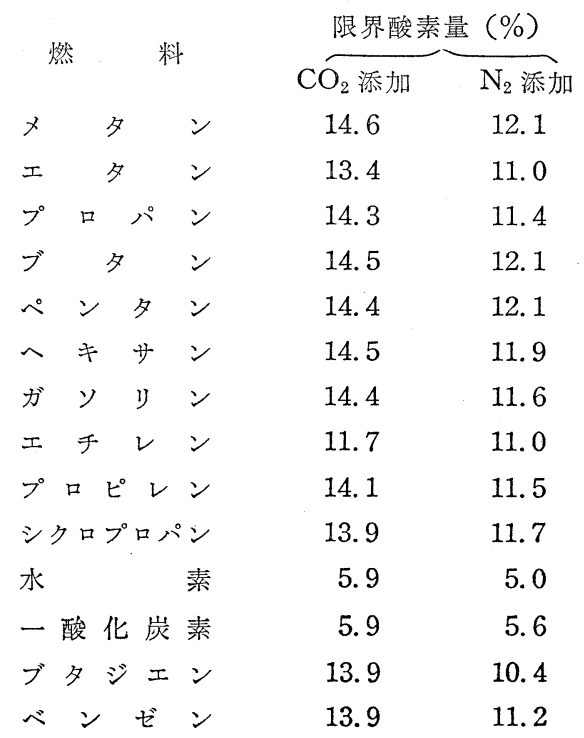

度が15\%以下になると起こらないといわれるのは多分 このような根拠によるものと想像される。その点, 限 界酸素量は添加ガスの種類によつて変わるもので, 一 律に何\%といらのは当たらない。この形式の消火法は 前記のように炭酸ガスや窒素ガスなどによる消火に利 用されているが, さらに最近はガス・タービンやジェ ット・エンジンの排気ガスなども連続的な不燃性ガス の発生源として用いられている。

\section{5. 添加物の燃焼抑制作用とその機構}

さてつぎには然焼の濃度条件による消火の内，八口 ゲン化合物のような特殊な化学作用を持つた添加物を 加えた三成分系の限界による消火を述べなくてはなら ないが，最初にも記したとおりこの方法は最近研究が 進んだもので現象としても興味深いので, ここでは章 を改めて記すことにする。

そのためには，まず然焼抑制作用を知つていないと いけないが，これは一口でいえば添加された物質が混 合気と化学的反忘を起こし, 燃焼を無添加の場合より 抑制する作用である。したがつて現象的にはこのもの の添加により燃焼速度, 火炎温度, 燃焼限界, 発光強 度などの燃焼および火災特性が変化し，正常な燃焼の 進展が阻害されるわけであるが, 機構的には添加物が 燃焼の継続に重要な役割を果たしている活性な化学種 (たとえば OH，H，O など）を除き去る役目を果た しているものと考えられている。以下これらの点につ いてもら少し詳細に考えてゆくが，現在の所，このよ らな燃焼を抑制する働きを持つ物質としてはハロゲ ンとアルカリ金属が知られていて両者はその作用が 多少ちがうので，ここではこれを別々に考えることに する。

まず八ロゲンによる燃焼特性の変化であるが, 図 3 , 図 4 に示した所 ${ }^{15)}$ からわかるように，一般に八ロゲン 化合物の蒸気を火炎に加えると火炎温度は加えられた 量に比例して低下し，また火炎中で然焼反応の主役を 演じているとみられる $\mathrm{OH}$ の発光強度も同様減少して いる。これらはいずれも拡散炎に添加したものである が，傾向は予混炎でも同じことで，明らかにハロゲン の添加は火炎特性の低下をきたす。一方, 燃焼速度も 図 5 の結果 ${ }^{16)}$ などからわかるように少量の添加で著る しく減少するから ${ }^{17)}$, これらの物質が火炎中の化学反 応に負の作用を持つことは明瞭で, 結局総合的には図 2 に示したように燃焼範囲は他の不活性な物質の添加 にくらべて少量で著しく狭くなる。そして,この傾向 は図 6 に示した臭化メチルの例 ${ }^{18)}$ からもわかるよらに 他の然料についても同一だから, 結局われわれはこれ 


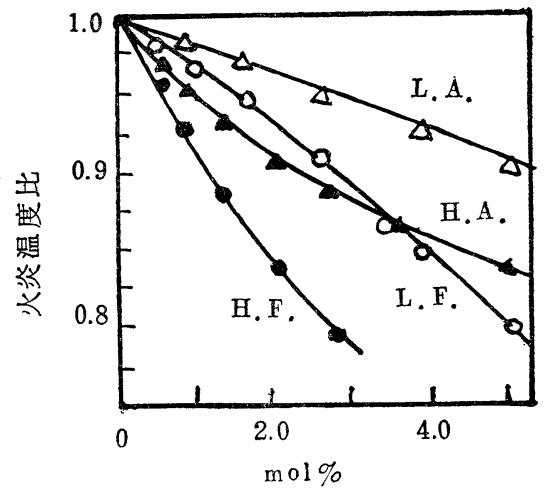

無添加に対する比, H.F.: 流速大で然料側 に添加, L.F.: 流速小で然料側, H. A.：流 流大で空気側, L. A.：流速小で空気側

図 3 メタン一空気拡散炎に四塩化炭素を入 れたときの火炎温度の変化

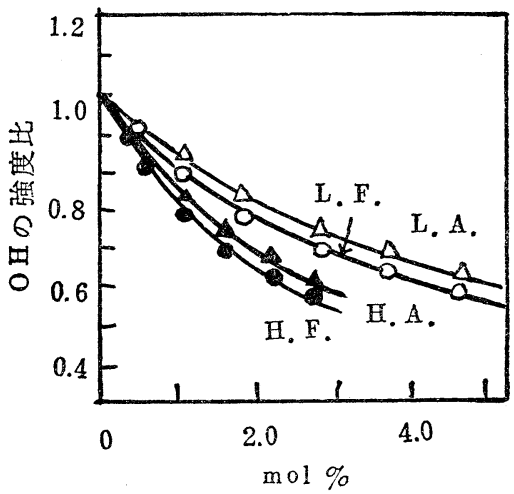

（記号以第 3 図と同じ）

图 4 水萦一空気旅散炎に臭素を入れたとき の $\mathrm{OH}$ 発光強度の変化

らの物質を添加することにより不活性物質より遙かに 少量で消火をすることができるわけであるが，つぎに は，この現象に付随して得られた上記以外の結果を列 記しておくと下のようになる。

（i）ハロゲンなどの添加による燃焼限界の変化は上 限界で著るしく下限界はあまり変わらない18)。(ii) 拡 散炎の場合, 添加剤は燃料側に入れるより空気側に入 れる方が効果が大きい199。(iii) 八ロゲンなどは前記 の各種の燃焼特性のほか燃焼の圧力限界を上昇させ る20)。（iv）燃燒限界のピーク值は燃焼速度の大きい 然料で高、 ${ }^{14)}$ 。(v) 同じ系統のハロゲン化炭化水素で は，ハロゲン含量の多いほど効果は大きく，またハロ

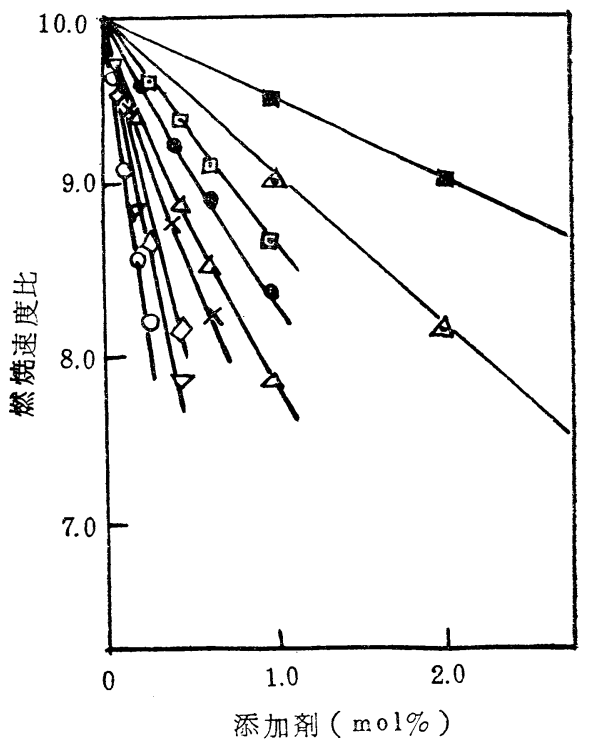

$\mathrm{H}_{2} \mathrm{O}, \Delta \mathrm{HCl}, \quad\left[\mathrm{CH}_{3} \mathrm{Cl}, \quad \mathrm{CH}_{2} \mathrm{Cl}_{2}\right.$ $\triangle \mathrm{CHCl}_{3}, \times \mathrm{CCl}_{4}, \diamond \mathrm{CH}_{2} \mathrm{I}, \nabla \mathrm{CH}_{3} \mathrm{Br}$, $\mathrm{CH}_{2} \mathrm{ClBr}$

図 5 プロパン一空気混合気に各種添加剂を 入れたときの燃焼速度の変化

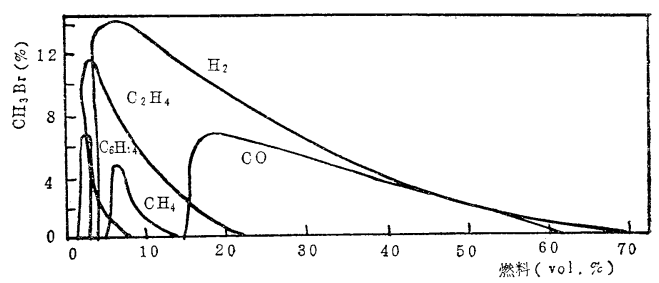

図 6 臬化ンチルを添加したときの各種燃料 一空気混合氮の燃焼限界

ゲンの中ではフッ素, 塩素, 真素, 沃素の順に效果は 増す16)21)23)。(vi) 燃焼抑制剂を添加するとその量に比 例して消炎亘径は増す22)。（vii）八ロゲンなどを添加 した火炎の $\mathrm{C}_{2}$ 発光強度は量の少ない閒はむしろ増加 するが，添加量が増すと減少する。これに対して CH 強度は添加による変化が著るしく小さい15)。

これらの結果は前のそれとともに然燒抑制作用の本 質を解明する上にきわめて重要なもので，これに基づ いて多くの機構が提案されている。しかしその中目下 の所で最も確からしいと考えられているのは Rosser ら ${ }^{23)}$ によつて発表されたつぎのようなものである。

$$
H \alpha+X \rightarrow H X+\alpha
$$




$$
\beta+H X \rightarrow X+H \beta
$$

ただしここに $H \alpha$ は水素を含む然料分子， $X$ は 八ロゲン原子， $\beta$ は燃焼の継続に必要な活性な化学種, H $\beta$ は不活性な分子であつて, 言葉でいえば八ロゲン 原子は燃料分子と反応して，八ロゲン酸を作り，そ れが $\mathrm{OH}$ などのラジカルを不活性な分子に変え, 自らは元のハロゲン原子に戻るとする考え方である。 この機構は反応サイクル中で八ロゲンが再生される ので，これが燃焼反応の停止するまで㗢くことにな り少量の添加で有効なことを説明するとともに, 前 に述べたハロゲンの種類による有効さの順序をハロゲ ン酸の結合エネルギーの大きさから解釈できる利点を もつ。つまり,八ロゲン酸の中臭化水素や沃化水素は結 合エネルギーが大きく, これらが火炎の反応域を通過 する間に解離することはないが，塩化水素などの場合 には炎の中で解離する割合が大きいので前記の第二の 反応の起こる可能性は小さく, したがつて塩素は臭素 や沃素より効果が小さいといらわけである。しかし，こ の反応経路が果たして正しいものであるかどらかは， 添加された八ロゲン化合物は直接分子状で $\mathrm{H}$ やHと 反応するといら最近の研究24225)26) もるるし，また抑制 効果の大きい物質は電子付着性功大きいところから， ロハゲンなどの燃焼抑制作用はこの点に密接な関係が

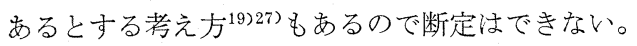

つぎに，アルカリ金属の作用については，このもの 涸体塩の形で火炎に添加されるため現象はむしろ不 均一系に属し，八ロゲンよりも複雑であるが, 前と同 様始めに実験的に得られた事実を列べてみるとつぎの ようになる。(i)アルカリ金属塩の添加はハロゲンと同 様に種々の炏炎および然焼特性を変化させるが，その 傾向は後者ほど判然としない，(ii）添加物質の粒子径 には最適の大きさがある ${ }^{28)}$, (iii) 溶融, 蒸発などが低 温で起こるものほど効果が大きい28)，(iv）アルカリ金 属の内ではリチウム，ナトリウム，カリウムの順に効 果は増す ${ }^{29)}$ 。参考として表 3 には蓚酸カリの粉末を用 いた場合の粒子径の影響 ${ }^{28)}$ をまた表 4 には各種粉末 の相対的な消火効果を比較した一例 ${ }^{30)}$ を示した。混合 気はともにメタンー空気系であり, 後の場合の尺度は消 火に必要な粉末量を燃焼速度で割つた值の逆数がとつ てある。これらの結果をみると粉末状抑制剤の場合, 粒子表面の化学的な作用とともに物理的な性質が重要 な役割を果たしていることがわかるが，化学的な機構 としては色々な考え方が提出されているものの現在は つきりしないといつた方がよいように思われる。たと えば，前に引用した Rosser ら゙3 はアルカリ金属塩は 火炎中で加熱されて原子状のアルカリ金属 $z$ になり, これがつぎのよらな反応で活性な化学種 $A, B$ を不活 性な分子にかえ燃焼を抑制するといら。

\section{表 3 伝ぱ火炎の消火に対する粒子径の効果}

(メタン空気火炎, 苳酸カリ粉末)

\begin{tabular}{|c|c|c|c|c|c|c|c|c|c|c|c|c|c|}
\hline 平均粒子径 ( $\mu$ ) & 1.78 & 3.06 & 3.09 & 3.46 & 5.24 & 7.00 & 11.7 & 36.3 & 70.1 & 87.5 & 90.4 & 119 & 132 \\
\hline 比表面積 $\left(\mathrm{cm}^{2} / \mathrm{g}\right)$ & 15,800 & 9,200 & 9,100 & 8,140 & 5.380 & 4,030 & 2,420 & 776 & 402 & 322 & 312 & 236 & 213 \\
\hline 消火必要量（mg） & no & 1,610 & 1,810 & 2,030 & 770 & 560 & 690 & 290 & 770 & 160 & 390 & 1,180 & 1,623 \\
\hline 全表面積* $\left(\mathrm{cm}^{2} / \mathrm{cm}^{3}\right)$ & & 27 & 30 & 30 & 7.6 & 4. 2 & 3.0 & 0.42 & 0.57 & 0.095 & 0.22 & 0.51 & 0.63 \\
\hline 平均粒子間距離 (mm) & & 0.033 & 0.034 & 0.037 & 0.080 & 0.113 & 0.177 & 0.74 & 1.02 & 2.15 & 1.65 & 1.51 & 1.51 \\
\hline
\end{tabular}

\section{表 4 アルカリ金属塩の相対的な燃焼抑制作用} (基準硫酸カリ)

\begin{tabular}{|c|c|c|c|c|c|c|c|c|c|}
\hline 質 & 名 & $\mathrm{KI}$ & $\mathrm{KNO}_{3}$ & $\mathrm{KBr}$ & $\mathrm{KCl}$ & $\mathrm{Na}_{2} \mathrm{CO}_{3}$ & $\mathrm{NaNO}_{3}$ & $\mathrm{NaCl}$ & $\mathrm{NH}_{4} \mathrm{Cl}$ \\
\hline 抑 制 効 & 果 & 0.7 & 0.6 & 0.5 & 0.4 & 0.4 & 0.3 & 0.2 & 0.2 \\
\hline
\end{tabular}

$$
\begin{aligned}
& A+z+M \rightarrow(A-z)+M \\
& (A-z)+B \rightarrow A B+z
\end{aligned}
$$

ただし，ここに $M$ は任意の第三体， $(A-z)$ は一 種の中閒複合物である。また Tiggelen $ら^{30)}$ も活性な 化学種 $R$ は固体粒子 $M$ と衡突し一時的にその表面に吸 着され，それが他の $R$ と反応するとして下のようなプ
ロセスを考えている。

$$
\begin{aligned}
& R+M \rightarrow M R \\
& R+M R \rightarrow R R+M
\end{aligned}
$$

しかし、これらの直接的な証明はなく“さらにナトリ ウムそのものを蒸気の形で添加しても効果はほとんど

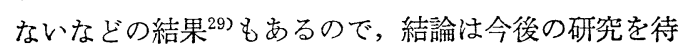


つベきであろう。

ところで，燃燒抑制作用を利用した実際の消火法と しては四塩化炭素を始めとする八ロゲン化炭化水素の 使用がある。従来これらの消火作用は不然性の重、蒸 気が火炎を覆い，空気の供給を妨げて消火する，前の 表現を用いれば然料と空気二成分系の燃燒限界にもと づくと考えられてきたが, BC(クロル・ブロム・メタン) の物理的性質は四塩化炭素之きわめて似ているにかか わらず，同一の炏炎を消すに必要な量は半分以下であ ることから疑問を持たれ，色々の解釈がなされたが， 近頃では，その差は今まで述べてきた含有八ロゲンの 燃焼抑制作用のちがいによるものと認められている。 したがつてその後塩素よりも効果の大きい臭素化合物 の開発が種々試みられてきたが，実用の消火剂となる 々消火効果以外に毒性, 腐食性, 価格などが問題にな るため現在三フッ化一臭化メタン，二臭化二フッ化メ タン，二臭化四フッ化エタンなどが多少使わ机ている にすぎない。一方アアルカリ金属塩については,ドライ ケミカルスの名称で重曹粉末が使用されているが，燃 燒抑制作用の点からいらと前記の所から重炭酸カリの 方が効力が大きいので最近はこの使用もふえている。 ただし，この種の粉末を窒素ガスで放射する形式の消 火法は，ここに述べてきた作用以外にも前に触れた火 炎からの熱輻射に対する遮蔽効果なども含まれるた め簡単には割り切れない点が多い。とくに最近万能消 火剤と名付けて売られているリン酸アンモンを主剤と した粉末などはこの系統とは別で，これが木材のよう な分解燃焼をする物質に有効なのはそれが木材中に浸 み込み熱分解形式をか光, 可然ガスの量や発生速度を 低下させるものとみられる。その意味ではリン酸アン モン系粉末の木質材料比する消火作用は前の二成分 系の燃焼限界の問題に帰着する。

\section{6. 燃焼の安定条件による消火}

前記の二つの条件が満たされれば然焼反応は開始す るかも知れないが，流れの条件が満足されない限り燃 焼の安定な継続はあり得ない。そこで，この条件を利 用して火炎を消すことも可能である。たとえば,予混炎 の場合, 火炎の安定化は混合気流速と燃焼速度の釣合 つた位置で起こり，流速が大きすぎると吹消え，小さす ぎると逆火を起こし，ともに火炎は消滅することはよ く知られたとおりである。市た, 拡散炎でも燃料流速ま たは空気流速が早くなると吹消えをおこして火炎は安 定化しない。これらの現象簡学にいえば火炎中にお ける化学反応に要する時間と流れにもとづいて物質が 運ばれる時間のバランスの問題で，発火に至る反応が
完了しない内に混合気が持去られてしまえば安定な火 炎はできないわけである。したがつてこの方法により 炎を消すためには反応に関係ある物質のどれか一つを 高速に流すことが要求される。しかし，実際問題となる と然料や混合気を速く流して吹消しを実現した場合, 生ガスの放出は消火以上の危険を伴うのでこの種消火 法の適用範囲はかなり狭く，そのような心配の少ない 固体や液体の拡散火炎を横方向から強い風を送る, こ とによつて消火する場合のみに使われている。マッチ の軸木の炎を吹き消すのはこの代表的な例であり，ま た油井の火災を火薬の爆風によつて消すのも原理的は にこれに属す。一般に燃焼の安定条件による消炎は工 業的に燃燒負荷を大きくしょうとする場合にしばしば 問題になるが，逆にこれを消火に用いようとすると困 難が多く, 前記の二つ以外には具体的な例を聞かない。

以上，おおまかであるが消火という現象を筆者なり に分類整理し，考え方の筋道を記した。もとより現象 はきわめて複雑であるから容易に説明できない点も多 く,またここでは敢て記述を避けた問題もある。たと えば，火炎に電界や磁界をかけると正負の電荷の分離 にもとづいて消炎する現象があるが，この種の現象は いまのところ消火法とは結びつかない上，説明によっ てはかえつて混乱をきたす恐れもあるので省略したわ けである。筆者の考えによれば, 消火の分野で現在最 も必要なことは, そのような未知の消火法ではなく, 従来使われている各種の方法に対する正確な現象論的 知識とその合理的な適用であるように思う。そしてこ の上に立つて始めて新らしい方法も開発されるのでは ないかと思われる。多くの考光違、や独断を含むとは 思うが，その意味でこの小文が多少ともお役に立てば 幸である。

\section{文献}

1) H. G. Wolfhard \& D. S. Burgess; Comb. \& Flame, 2, 3 (1958)

2) J.E. Dolan; 6th Symp. on Comb., p. 787 (19d7)

3) P. Laffitte \& R. Bouchet; 7th Symp. on Comb., p. 504 (1959)

4) K.N. Palmer; 7th Symp. on Comb., p. 497 (1959)

5) K. N. Palmer; 1st Symp. on Chem. Process Hazards, p. 51 (1961), 2nd Symp. on Chem. Process Hazard, p. 15 (1963)

6）秋田編 “可燃性混合気の最小発火エネルギーと消 炎距離”, 災害科学研究会資料 (1966) 
7) D. T. Rasbash \& W. Rogowski; Comb. \& Flame, 1, 453 (1957), 4, 223 (1960), Chem. Ind., 693 (1953)

8) G.W. Jones, W. H. Gilliland: U. S. Bur. Mines Rept., Invest., No. 3871 (1946)

9) "Symp. on Fire Fighting Form"; Ind. Eng. Chem., 48, 2013 20 (1956)

10) B. Langford, G. W. Stark, \& D. J. Rasbash; Fire Res. Note, No. 511,519, (1962), 546 (1963)

11) R. L. Tuve, H. B. Peterson, E. J. Jablonski \& R. R. Neill; Naval Res. Lab., Rept., No. 6057 (1964), Quart. NFPA 58, 64 (1964)

12) J. L. Risinger; Quart. NFPA 46, 83 (1952)

13) C.S. McMamy, H. Shoub \& T. G. Lee; 6th Symp. on Comb., p. 795 (1957)

14) B. Lewis \& G. Von E: be; "Combustion, Flames and Explosion of Gases", Appendix B, p.702 (1960)

15) M. M. I biricu \& A. G. Gaydon; Comb. \& Flame, 8, 51 (1964)

16) F. M. Garner, R. Long, A. J. Graham \& A. Badakhsham; 6th Symp. on Comb., p. 802 (1957)

17) C. Halpern; J. Res. Nat. Bur. Stand., 67A. 71 (1963)

18) J.H. Burgoyne \& G. Williams-Leir; Proc. Roy. Soc., A. 193, 525 (1948)

19) E. C. Creitz; J. Res. Nat. Bur. Stand., 65 A, 389 (1961)

20) F. E. Bells \& C. O'neal; 6th Symp. on Comb., p. 806 (1957)
21) F.H. Coleman; Fuel 30, 114 (1951), 31, 445 (1952)

22) W. A. Rosser, Jr., S. H. Irami \& H. Wise; Comb. \& Flame, 10, 287 (1966)

23) W.A. Rosser, Jr., H. Wise \& J. Miller; 7th Symp. on Comb., p. 175 (1959)

24) C. P. Fenimore \& G. W. Jones; Comb. \& Flame, 7, 323 (1963)

25) W.E. Wilson, Jr.; 10th Symp. on Comb., p. 47 (1965)

26) G. B. Skinner \& G.H. Ringrose; J. Chem. Phys., 43, 4129 (1965)

27) T. G. Lee; J. Phys. Chem., 67, 360 (1963)

28) P. Laffitte, R. Delbourgo, J. Combourieu \& J. C. Dumont; Comb. \& Flame., 9, 357 (1965)

29) R. Friedman \& J. B. Levy; Comb. \& Flame, 7, 195 (1963)

30) M. Dewitte, J. Vrebosch \& A. Van Tiggelen; Comb. Flame, 8, 257 (1964)

31) W.A. Rosser, Jr., S.H. Inami \& H. Wise; Comb. \& Flame, 7, 105 (1963)

（注）ここに与えた文献はおもなもののみで完備した ものではなく，また燃焼に関するものは全て除い た。そこで多少古いが消火に結びついた燃焼の文 献が比較的多く集めてある総説を終りに二つだけ 示しておく。

B.S. Maney \& B. C. Lindley; "Flame quenching”, J. Royal Aeronat. Soc., 62, 32 (1958)

$\bigcirc$ S. S. Penner \& B. P. Mullins; Explosions, detonations, flammability and ignition, part II. (1959) Pergamon Press.

\title{
Principle of Flame Extinction
}

\author{
by Kazuo Akita
}

\section{(University of Tokyo)}

SYNOPSIS :-The mechanism of flame extinction is classified into three groups of (1) quenching due to heat loss (thermal effect), (2) quenching based on flammability limits (chemical effect), and (3) quenching by flame stabilizing limit (aerodynamic effect), and the foundamental problems of each mechanism are discussed from a stand- 
point of combustion physics and chemistry. In first group, the utilization of heat dissipation due to solid surface such as wire gauze, inert powder and porous metals, and the latent heat of li juid vaporization are dealt with, in second group, the limits of inflammability of fuel-air mixtures and the effect of additives as inert gases and inhibitors are main subject, and in last group, the possibility of using the blow off of flame by high speed air flow is discussed.

In particula, author spends much space for the combustion inhibiting effect of halogenated hydrocarbons and alkali metal salts under expectation of appearance of more effective method for fire extinction. 